\title{
The use of the female condom by women in Brazil participating in HIV prevention education sessions
}

\author{
Elisabeth Meloni Vieira, ${ }^{1}$ Alcyone Artioli Machado, ${ }^{2}$ Geraldo Duarte, ${ }^{3}$ \\ Regina Helena Brito de Souza, ${ }^{4}$ and Antonio Luis Rodrigues Junior ${ }^{1}$
}

Suggested citation Vieira EM, Machado AA, Duarte G, Souza RHB de, Rodrigues Junior AL. The use of the female condom by women in Brazil participating in HIV prevention education sessions. Rev Panam Salud Publica. 2004;15(6):373-79.

ABSTRACT Objectives. To study HIV-positive women and women at risk of becoming infected with HIV who attended HIV prevention education group sessions at a university hospital in Brazil and to compare the use of the female condom and the male condom by these two groups of women.

Methods. The study subjects were 165 women participating in HIV prevention education group sessions at the Medical School Hospital of Ribeirão Preto of the University of São Paulo, in the city of Ribeirão Preto, São Paulo, Brazil. Women could be enrolled in the study from August 2000 to June 2001, and the follow-up observation time period was from August 2000 to July 2001. Male condoms and female condoms were freely distributed to all the participants at the end of each educational session and also at the end of each follow-up visit that the participants made. Each woman took part in an initial interview and was asked to return monthly. At each follow-up visit an additional short interview was carried out in order to investigate use of the male condom and of the female condom. Variables that were examined for the study included age, education, ethnic group, marital or relationship status, number of children, the women's use of male condoms and female condoms, commercial sex (whether the women had ever had sex in exchange for money, gifts, or favors), and previous knowledge of the female condom.

Results. The 165 women studied fell into the following three categories: 132 of them $(80.0 \%)$ were HIV-positive, 26 of them (15.8\%) had a sexually transmitted disease (STD) other than HIV and did not have an HIV-positive partner, and 7 of them (4.2\%) had an HIV-positive partner but did not have HIV or any other STD. The women ranged in age from 15 to 64 years, with a mean of 30.3 years. Of the women in the study, $69.7 \%$ of them were married or were cohabitating, and $90.9 \%$ of them had a sexual partner. Just over two-thirds of the women had seven years of formal schooling or less. Out of 163 women, a total of 31 of them (19.0\%) had never used the male condom with a partner, and 49 of the 163 (30.1\%) had not used a male condom at the time of the last sexual intercourse. Out of the 165 women, 74 of them $(44.8 \%)$ returned for at least one follow-up visit. Of these 74 women, 58 of them (78.3\%) reported

University of São Paulo, Medical School of Ribeirão Preto, Department of Social Medicine, Ribeirão Preto, São Paulo, Brazil. Send correspondence to: Elisabeth Meloni Vieira, Faculdade de Medicina de Ribeirão Preto-USP, Departamento de Medicina Social, Av. dos Bandeirantes $39002^{\circ}$ andar,
14049-900 Ribeirão Preto, São Paulo, Brazil; telephone: 55-16-602-2538/602-2433; fax: 55-16-633-1386 e-mail: bmeloni@fmrp.usp.br

2 University of São Paulo, Medical School of Ribeirão Preto, Department of Internal Medicine, Ribeirão Preto, São Paulo, Brazil.
3 University of São Paulo, Medical School of Ribeirão Preto, Department of Gynecology and Obstetrics, Ribeirão Preto, São Paulo, Brazil.

4 University Hospital of the Medical School of Ribeirão Preto, Ribeirão Preto, São Paulo, Brazil. 
using the female condom between the initial interview and the first follow-up visit. The majority of the 74 women who returned for a visit liked using the female condom, and the women reported that their partners also generally accepted the female condom. In comparison to women at risk of HIV, HIV-positive women were more likely to have used the male condom with a partner before the initial interview. Women who continued returning over a longer follow-up period were more likely to have used the female condom at the time of the last sexual intercourse. No association was found between female condom use at the time of last sexual intercourse and the woman's HIV infection status.

Conclusions. In comparison to the women at risk of HIV, the HIV-positive women in our study were more likely to use male condoms with their partners, to return for follow-up visits, and to have a longer follow-up period. The acceptance of the female condom among the HIVpositive women in this study, as reported at their first follow-up visit, appears to be similar to the acceptance of the female condom among women in general in Brazil.

Key words Condoms, female; condoms; acquired immunodeficiency syndrome; HIV infections; sexually transmitted diseases; safe sex; Brazil.

The HIV / AIDS epidemic is a major public health concern in Brazil. As in many other countries, the spread of HIV/AIDS has been increasing rapidly among women. AIDS is one of the major causes of death among women of reproductive age in Brazil. ${ }^{5}$ In São Paulo, which is the most populous state of Brazil, AIDS has been the leading cause of death among women aged 15 to 49 years old since 1991 (1).

Brazilian women who are in need of protection against HIV face many obstacles in negotiating for safer sex (2, 3). Gender inequalities in the area of sexual activity place women at a disadvantage, limiting their ability to negotiate for safer sex due to problems with communication, fear, coercion by the partner, and financial or emotional dependency (4).

The female condom (FC) has the advantage of being under a woman's control and initiative (5). Experience in various countries around the world has shown that the FC empowers women, insofar as it helps them negotiate protection with a partner, promotes healthy behavior, and increases sexual confidence and autonomy (6).

The FC was first introduced in Brazil in 1996, in a study of women's ac-

\footnotetext{
5 Jorge MHP de, Gotlieb SLD, Laurenti R. Aids na mulher: o ganho na informação de mortalidade. Ciênc Saúde Coletiva. 2003;8(supl 1):116.
}

ceptance of it (7). In a study (8) conducted in the city of São Paulo (which is Brazil's largest city and also the capital of the state of the same name) women who had a greater perception of risk were more likely to use the FC than were women with less perception of risk. In addition, women who talked to their husbands about HIV and asked them to wear a male condom were more likely to try the FC (8).

After a comprehensive study in several public health centers (9) the Brazilian Ministry of Health decided to implement a policy of free female condom distribution in the country. There were two priority target populations for this effort: (1) HIV-positive women and (2) women at risk of becoming infected with HIV (including commercial sex workers, women with an HIV-positive partner, and women who had a sexually transmitted disease (STD)). A particular reason for this decision was earlier research showing that HIV-positive women have difficulty in convincing a partner to use the male condom, especially a regular or stable partner (10).

For our study, male condoms and female condoms were freely distributed to 165 women who participated in HIV prevention education group sessions at the Medical School Hospital of Ribeirão Preto of the University of São Paulo, in the city of Ribeirão Preto, São Paulo, Brazil. At the Medical School Hospital the women were attending one of two clinics: the Special Unit for the Treatment of Infectious Diseases or the Gynecology Outpatient Clinic.

In our study we offered the FC to HIV-positive women and to women at risk of becoming infected with HIV (women who were HIV-negative but had an STD other than HIV or had a sexual partner who was HIV-positive). Commercial sex workers were not a target population for our study since we considered the hospital setting inadequate for a specific study on this population group.

This study was conducted as an independent initiative of an academic research group. We decided to investigate the use of male and female condoms among these groups of women for two primary reasons. First, the Brazilian Ministry of Health has provided female condoms to be freely distributed. Second, there were few studies reporting on the use of the female condom among HIV-positive women.

The objective of our research was to compare the profile of HIV-positive women and of women at risk of becoming infected with HIV who were offered the FC and to report on the use of female condoms and male condoms by these two groups of women. 


\section{MATERIAL AND METHODS}

Twice a week for a year, from August 2000 to July 2001, all women present in the waiting rooms of the two clinics were invited to participate in the group education sessions. The sessions were held in a private room and conducted by two psychologists and a social worker. The sessions introduced the FC and its use. The group coordinators also provided information about HIV/STD prevention, use of the male condom, and other subjects that women in the group raised. Male condoms and female condoms were freely distributed to all participants at the end of each educational session as well as at every follow-up visit that the participants made. Each woman took part in an initial interview and was asked to come back to the clinic the following month. Women were instructed to return earlier if they needed more male condoms or female condoms or further instruction on the FC. The instructions were the same for all the women, except that HIV-positive women were also told they should return more regularly in order to receive anti-HIV drugs.

We examined variables for the women that included age, education, ethnic group, marital status, children, condom use, commercial sex ("Have you ever had sex in exchange for money, gifts, or favors?"), and previous knowledge of the FC. In terms of male or female condom use, several aspects were explored: previous use, the frequency of use (always, sometimes, never), and use at the last sexual intercourse. Each follow-up visit had an additional short interview that also investigated the use of the male condom and the female condom. Women who asked for more female condoms or male condoms during the follow-up visit received them.

For our study the use of male condoms was considered from the period of time immediately before the first education group session until the last sexual intercourse reported during a follow-up visit. The use of the FC was considered from the time immediately after the first education group session until the last sexual intercourse reported during a follow-up visit.

The recruitment period for enrollment in the study was from August 2000 to June 2001, and the follow-up observation period was from August 2000 to July 2001. Therefore, the maximum length of follow-up was 12 months and the minimum was one month. Women were admitted into this dynamic cohort as they came for a visit to the health service. The person-time scale (persondays) was considered for statistical analysis of follow-up (11).

To study the length of the follow-up time the Kaplan-Meyer technique was used when the independent variable was categorical, and Cox regression when the independent variable was an interval. The observed event was the length of time of participation in the study, measured in the number of days (12). The length of time that women used the male condom and the female condom during their participation in the study was analyzed by the nonparametric Kruskal-Wallis test (13). Logistic regression was used to analyze the information obtained from the initial questionnaire on prior use of the male condom. The Pearson's chisquare test and the Fisher's exact test were used for the statistical analyses. Using the Stata statistical software package (StataCorp LP, College Station, Texas, United States of America), statistical tests were used to search for associations among the variables.

Women's opinions on the female condom as well as their partners' opinions, as reported by the women, were collected through open-ended questions and were analyzed as descriptive qualitative data.

\section{RESULTS}

\section{Characteristics of the sample}

The 165 women studied fell into the following three categories: 132 of them $(80.0 \%)$ were HIV-positive, 26 of them $(15.8 \%)$ had an STD that was not HIV and did not have an HIV-positive partner, and 7 of them (4.2\%) had an HIV- positive partner but did not have HIV or any other STD.

Among the 132 HIV-positive women, a total of 121 of them $(91.6 \%)$ had a sexual partner. Among these 121 women, 53 of them $(43.8 \%)$ reported having a partner with the same serological status, 61 of them $(50.4 \%)$ had a serodiscordant partner, and 7 of the women $(5.8 \%)$ reported that they did not know their partner's serological status.

The 165 women participants ranged in age from 15 to 64 years, with a mean of 30.3 years. The single largest age group (67 of 165 , or $40.6 \%$ ) was from 30 to 39 years old; $26.7 \%$ (44 of 165 ) were from 25 to 29 years old; $21.8 \%$ (36 of 165) were from 15 to 24 years old; and $10.9 \%$ (18 of 165) were in the older age group, of 40 to 64 years old. In terms of relationship status, 41 of the 165 $(24.8 \%)$ were married, and 74 of them $(44.8 \%)$ were cohabiting. The other women were single (26 of 165 , or $15.8 \%$ ), divorced (13 of 165 , or $7.9 \%$ ), or widowed (11 of 165 , or $6.7 \%$ ). A total of 150 of the 165 women $(90.9 \%)$ reported having a sexual partner. Only 13 of the 165 women $(7.8 \%)$ had been involved in commercial sex. The general levels of education were low among the women: 32 of 165 (19.4\%) had less than four years of schooling, including 4 women who were illiterate; 78 of 165 $(47.3 \%)$ had from four to seven years of schooling; and 55 of 165 (33.3\%) had eight or more years of schooling.

Variables describing the sample were tested in order to investigate the differences between the HIV-positive women and the women at risk of becoming infected with HIV. Three associations were found: age, having children, and male condom use. While $48.5 \%$ (16 of 33) of the women at risk for HIV infection were aged between 15 and 24 years old, only $15.2 \%$ (20 of 132) of the HIV-positive women were in this age group (Pearson's chi-square $=$ $17.8506, P<0.001)$. More of the women with HIV had children (123 of 132, or 93.2\%) than was true for the women at HIV risk (21 of 33, or 63.6\%) (Pearson's chi-square $=20.7472, P<0.001$ ). HIV-positive women were also more likely to have a partner who used a 
male condom before the educational sessions.

\section{Previous male condom use}

At the initial interview 114 of 163 women $(69.9 \%)$ reported male condom use at the time of the last sexual intercourse (2 women did not answer this question). When asked, "Does your partner use a male condom?," 96 of the 163 women (58.9\%) answered "always," 36 of the women $(22.1 \%)$ answered "sometimes," and 31 of the women (19.0\%) answered "never." The HIV-positive women were six times more likely to use male condoms with their partners than were the women at HIV risk $(P=0.060)$.

\section{Number of follow-up visits}

During the follow-up period of 12 months, 91 of the 165 women $(55.2 \%)$ did not return for a follow-up visit and 74 of the 165 women returned at least once. The number of follow-up visits made by these 74 women ranged from one to seven: 13 of the 165 women $(7.9 \%)$ made one visit, 36 of them $(21.8 \%)$ returned twice, 15 of them $(9.0 \%)$ returned for three visits, 7 of them (4.2\%) returned for four visits, and 3 of them $(1.8 \%)$ returned more than four times (one returned for five visits, one returned for six visits, and one returned for seven visits).

The first follow-up visit occurred an average of two months after the initial interview. Returning for the first follow-up visit was found to be associated with HIV-positive status; $51.5 \%$ (68 of 132) of the HIV-positive women returned for the first follow-up visit, compared to only $18.2 \%$ (6 of 33) of the women at HIV risk $(P=0.001)$. Two other variables were found to be associated with follow-up visits: relationship status and the partner's serological status. Of the 115 women who were married or were cohabitating, 58 of them $(50.4 \%)$ returned for follow-up, but only 16 of the 50 women $(32.0 \%$ of them) who were single, divorced, or widowed returned $(P=0.029)$. More women with HIV-negative partners (66 of 105 , or $62.8 .0 \%$ ) returned for followup than did women whose partners were HIV-positive (26 of 60 , or $43.4 \%$ ) $(P=0.003)$.

\section{Length of time of follow-up}

During the 12-month follow-up period, the length of time over which individual women made follow-up visits ranged from one month to 325 days. The median length of time of followup, considering all visits, was 74 days. There was a significant difference $(P=$ 0.0169) between HIV-positive women and women at risk of becoming infected with HIV in terms of the length of follow-up. Figure 1 shows survivor curves by the Kaplan-Meyer method, comparing women who were HIVpositive with women who were at risk of becoming HIV-infected.

While the HIV-positive group had a median follow-up period of 120 days, women at risk of HIV had a median of 42 days $(P=0.0169)$. Length of follow-up was associated with years of schooling. Women with more than eight years of schooling were more likely to have a longer followup period than were women with fewer years of schooling $(P=0.042)$. The use of a FC at the time of last sexual intercourse after the education group session was also associated with longer follow-up ( $P=0.0118)$. Women who did not use the FC at the time of last sexual intercourse had a shorter mean time of follow-up (91 days) than did women who used the FC (126 days). No other variable was found to be associated with length of follow-up.

\section{Female condom use}

Of the 165 women, 99 of them $(60.0 \%)$ had already heard about or seen the FC before the education session. Among the 74 women who attended the first follow-up, 58 of them (78.3\%) reported using the FC during the time period between the education session and the first follow-up visit.
Among the 16 of these 74 women who did not use the FC, their reasons included: they had not had sexual intercourse ( 8 of 16 , or $50.0 \%$ ), it was difficult to manipulate the device (4 of 16 , or $25.0 \%$ ), and there had been opposition from their partner (4 of 16, or $25.0 \%$ ). No association was found between the use of the male condom or the female condom at the time of last sexual intercourse and the HIV serological status (positive or negative) of the woman's partner. No difference was found in the use of the male condom and the female condom between couples who were serodiscordant (one HIV-positive and the other HIVnegative) and couples who were both HIV-positive.

\section{Opinions on the female condom}

Among the 58 women who actually used the FC between the education session and the first follow-up visit, 21 of them $(36.2 \%)$ reported at that first follow-up visit that they "liked it very much," 26 (44.8.\%) reported they "liked it," and $11(19.0 \%)$ said they "did not like it." The 58 women also reported at the first follow-up visit their partners' opinions of the FC: 17 of the $58(29.3 \%)$ said their partners "liked the FC very much," 21 (36.2\%) said they "liked it," $8(13.8 \%)$ reported "no opinion," and 12 of the women (20.7\%) said their partners "hated it."

Among the reasons women gave for liking the FC was that their partners felt that the FC was much better than the male condom. Among reasons for disliking the FC, women mentioned aesthetic reasons or fitting problems during sexual intercourse.

The women reported their partners' likes and dislikes regarding the FC. Among the specific positive comments on the FC were:

\section{He found it to be excellent!}

He thinks it's better than the male condom.

He liked it because the male condom is tight.

He liked it! It's 1000 times better.

He liked it. He did not feel it. 
FIGURE 1. Kaplan-Meyer curves showing dropout pattern during the follow-up period, for HIV-positive women and for women at risk of HIV, Brazil, 2000-2001

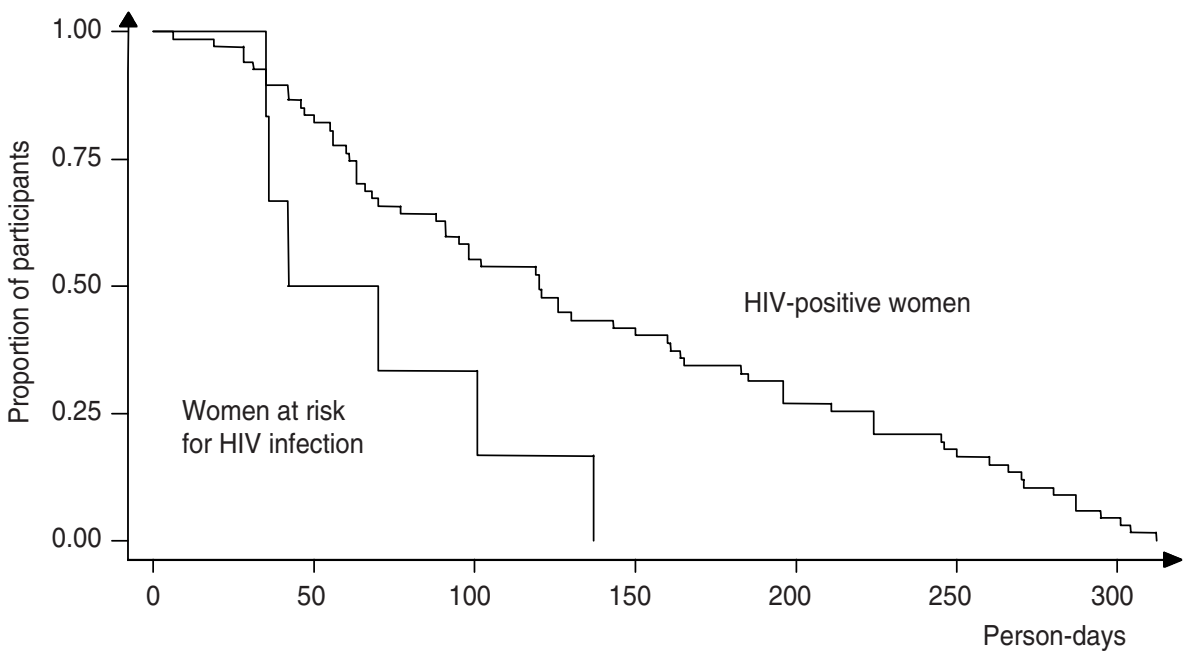

Among the unfavorable comments the women reported were:

From the moment he saw it he did not like it.

He did not like it. He said it seems like a large bag. It's ugly!

He did not like it because it came out during sex.

He did not like it. The condom did not fit. He did not like it. He lost his erection.

\section{DISCUSSION}

In 1996, $11.4 \%$ of Brazilian women and $30.8 \%$ of Brazilian men in the general population reported male condom use in the last sexual intercourse (14). Although the $69.9 \%$ male condom use among the women whom we studied was considerably higher than that in the general population, a total of 31 of 163 women $(19.0 \%)$ reported at the initial interview that they had never used the male condom. Furthermore, 49 of 163 women $(30.1 \%)$ reported they had not used the male condom with their partner at the time of the last sexual intercourse. Considering the protection that these women need, an alternative to the male condom should be offered for various reasons, including the fact that protected sexual activity decreases HIV reinfection among HIVpositive individuals (15).

For HIV protection, the FC is the only alternative to the male condom. However, use of the FC depends on how much control a woman has if her partner does not agree to use a male condom (16). Other studies have shown that use of the FC increases protection among HIV-positive women and STD patients. A study of HIV-positive women in Brazil using the FC showed a reduction from $14 \%$ to $6 \%$ in the proportion of unprotected sexual intercourse (17). Another study, which examined the acceptability of the female condom among 1159 STD patients in the United States, found that more than one-third of those who completed the study used the FC throughout the six months of follow-up (18).

In contrast with other recent studies on the acceptability of the FC in Brazil, in this study we found that fewer than half of the women returned for a follow-up visit. The explanation may lie in the main limitation of this study: It was carried out in a highly specialized university hospital instead of an easily accessible primary care clinic. Recent studies in Brazil reported that the acceptability of the FC varied from $68 \%$ among HIV-positive women (17) to $83.3 \%$ among users of the public health system. ${ }^{6}$ Compliance with FC use by low-income women as reported on the 90th day after starting to use the FC reached $80 \% .{ }^{7}$ However, a large majority of the women who returned for the first follow-up visit in our study reported using the FC, a large majority of them reported they liked using the device, and a majority of them reported that their partners also liked the FC.

In comparison to the women at risk of HIV, the HIV-positive women in our study were more likely to use male condoms with their partners, to return for follow-up visits, and to have a longer follow-up period. These behaviors reflect the high level of awareness that the HIV-positive women have of the need to protect themselves.

We found that HIV-positive women who were married or were cohabitating were more likely to return for follow-up visits than were either HIVpositive women who were not married or women at risk of HIV infection. Women with an HIV-negative partner were also more prone to return for follow-up visits. These patterns may reflect these women's awareness of the need to protect others. The role of women as caregivers has been thoroughly examined in a recent study (19).

\section{CONCLUSIONS}

When all the factors studied in this investigation are taken into consideration, acceptance of the FC among HIVpositive women at the first follow-up visit of this study appears to be similar to overall acceptance of the FC among the general population in Brazil, according to other studies that did not investigate FC use specifically among HIV-positive women. This result underscores the fact that use of the FC is

\footnotetext{
6 Friedman RK, Andrade A, Costa RLB, Grinsztejn B, Veloso VG, Liporage J, et al. Acceptability of female condom in a cohort of HIV infected women in Rio de Janeiro, Brazil. XIV International AIDS Conference, 7-12 July 2002, Barcelona, Spain.

7 Kalckmann S, Barbosa R. Compliance to female condom among low-income women during 12 month-period in Brazil. XIV International AIDS Conference, 7-12 July 2002, Barcelona, Spain.
} 
an important alternative that can lead to safer sex.

Our study also shows that there is an urgent need to improve knowledge of HIV protection among women at risk of HIV infection. We found that the differences between HIV-positive women and women at risk of becoming infected with HIV had more to do with protective behaviors such as condom use than with the women's background variables, except for their age.
Given these differences in behavior, it appears to be only a matter of time before women at risk of HIV become infected with the virus.

When planning prevention initiatives, one should take into account the fact that the FC is fairly well accepted among women and men in Brazil. This facilitates promotion and attainment of more widespread use. However, to improve FC use, strategies are still needed to overcome the difficulties involved in handling the FC and to encourage men to support women in using it.

Acknowledgment. The authors are very grateful to Beatriz Ali Segatto and Taís de Carvalho Pandolfi, the psychologists who conducted the educational group discussion, and to Elspeth J. Mathie, for her suggestions on this paper.

\section{REFERENCES}

1. Santos N, Ventura-Fillipe E, Paiva V. HIVpositive women, reproduction and sexuality in São Paulo, Brazil. Reprod Health Matters. 1998;6(12):31-40.

2. Heise L, Elias C. Transforming AIDS prevention to meet women's need: a focus on developing countries. Soc Sci Med. 1995;40:931-43.

3. Barbosa RM. Negociação sexual ou sexo negociado [doctoral thesis]. Rio de Janeiro: Instituto de Medicina Social da Universidade Estadual do Rio de Janeiro; 1997.

4. Sherr L. Tomorrow's era: gender, psychology and HIV infection. In: Sherr L, Hankins C, Bennet L, eds. AIDS as a gender issue: psychological perspectives. London: Taylor \& Francis; 1996. Pp. 16-45.

5. World Health Organization. The female condom. A review. Geneva: WHO; 1997.

6. Gollub EL The female condom: tool for women's empowerment. Am J Public Health. 2000;90(9):1377-81.

7. Kalckmann AS, Réa MF, Villela WV, Fernandes MEL, Vieira EM, Ankrah EM. The female condom as a woman-controlled protective method. São Paulo, Brazil. Summary report. Arlington: AIDSCAP Women's Initiative/ Family Health International; 1997.
8. Buchalla CM, Carvalho MHM, Fernandes MEL, Vieira EM, D'Angelo LAV, Pinotti JA. Aceitabilidade do preservativo feminino entre mulheres atendidas no Centro de Referência da Saúde da Mulher, Nutrição e Alimentação e Desenvolvimento Infantil. Rev Gin Obstet. 1998;9(1):12-8.

9. Brazil, Ministry of Health. Acceptability of the female condom in different social contexts. Final research report. Brasilia: $\mathrm{MOH} ; 2000$.

10. Barbosa RM. HIV/AIDS, transmissão heterossexual e métodos de prevenção controlados pelas mulheres. Rio de Janeiro: Associação Brasileira Interdisciplinar de AIDS; 2000. (Coleção ABIA Saúde Sexual e Reprodutiva, 2).

11. Rothman K, Greenlands S. Modern epidemiology. Philadelphia: Lippincott-Raven Publishers; 1998.

12. Lee E. Statistical methods for survival data analysis. 2nd edition. New York: Wiley; 1992.

13. Conover WJ. Practical nonparametric statistics. New York: Wiley; 1971.

14. Badiani R, Quental I, Santos EM. DST/AIDS e a Pesquisa Nacional sobre Demografia e Saúde: uma análise do nível de conhecimento e comportamentos de vulnerabilização. Rio de Janeiro: BEMFAM, Macro; 1997.
15. Jones DL, Weiss SM, Malow R, Ishii M, Devieux J, Stanley $\mathrm{H}$, et al. Brief sexual barrier intervention for women living with AIDS: acceptability, use and ethnicity. J Urban Health. 2001; 78(4):593-604.

16. Susser I. Health rights for women in the age of AIDS. Int J Epidemiol. 2002;31:45-8.

17. Magalhães J, Rossi A da S, Amaral E. Uso de condom feminino por mulheres infectadas pelo HIV. Rev Bras Gin Obstet. 2003;25(6):389-95.

18. Artz L, Macaluso M, Brill I, Kelaghan J, Austin $\mathrm{H}$, Fleenor $\mathrm{M}$, et al. Effectiveness of an intervention promoting the female condom to patients at sexually transmitted disease clinics. Am J Public Health. 2000;90(2):237-44.

19. Bennet L, Casey K, Austin P. Issues for women as carers in HIV/AIDS. In: Sherr L, Hankins C, Bennet L. AIDS as a gender issue: psychological perspectives. London: Taylor \& Francis; 1996. Pp. 177-90.

Manuscript received 15 January 2003. Revised version accepted for publication 1 March 2004. 
RESUMEN Objetivos. Estudiar a las mujeres con seropositividad a VIH, así como a mujeres en riesgo de infección por $\mathrm{VIH}$, que asistieron a sesiones grupales educativas sobre la prevención del VIH en un hospital universitario en Brasil, y comparar el uso del con-

\section{El uso del condón femenino por mujeres en Brasil que participan en sesiones educativas sobre el VIH}

dón femenino y masculino en estos dos grupos de mujeres.

Métodos. Se estudió a 165 mujeres que participaban en sesiones grupales educativas sobre la prevención del VIH en el Hospital Docente de Riberão Preto, dependencia de la Facultad de Medicina de la Universidad de São Paulo, en la ciudad de Riberão Preto, Brasil. El período de inscripción en el estudio duró de agosto de 2000 hasta julio de 2001, y el período de observación posterior, de agosto de 2000 hasta julio de 2001. Se distribuyeron condones masculinos y femeninos gratuitamente a todas las participantes al final de cada sesión educativa, así como al final de cada una de las consultas de seguimiento. Cada mujer tomó parte en una entrevista inicial y a cada una se le pidió que regresara cada mes. En cada consulta de seguimiento se llevó a cabo otra entrevista corta para investigar el uso del condón masculino y femenino. Las variables examinadas para el estudio fueron la edad, escolaridad, grupo étnico, estado civil o de convivencia con pareja, número de hijos, uso del condón masculino o femenino entre las mujeres, relaciones sexuales comerciales (si las mujeres habían tenido alguna vez relaciones sexuales a cambio de dinero, regalos o favores) y conocimiento previo de la existencia del condón femenino.

Resultados. Las 165 mujeres estudiadas pertenecían a las tres categorías siguientes: $132(80,0 \%)$ tenían seropositividad al VIH, $26(15,8 \%)$ tenían una enfermedad de transmisión sexual (ETS) y $7(4,2 \%)$ tenían una pareja con seropositividad a VIH pero no tenían ni infección por VIH ni ninguna otra ETS. Las mujeres estaban entre los 15 y 64 años de edad, con una edad promedio de 30,3 años. De las mujeres estudiadas, $69,7 \%$ estaban casadas o vivían con su pareja y $90,9 \%$ tenían un compañero sexual. Un poco más de dos tercios de las mujeres tenían siete años de educación formal o menos. De las 163 mujeres, un total de $31(19,0 \%)$ nunca habían usado el condón masculino al tener relaciones con una pareja, y 49 de las 163 (30,1\%) no habían usado el condón masculino durante el acto sexual más reciente. De las 165 mujeres, 74 (44,80\%) regresaron a por lo menos una de las consultas de seguimiento. La mayoría de estas $74 \mathrm{mu}$ jeres que acudieron a su seguimiento aprobaban del condón femenino. Cuando se les comparó con mujeres en riesgo de infección por VIH, las mujeres con seropositividad a VIH tenían mayores probabilidades de haber usado el condón masculino con una pareja antes de la primera entrevista. Las mujeres que siguieron volviendo a consultas durante un período de seguimiento más largo tenían más probabilidades de haber usado el condón femenino durante el acto sexual más reciente. No se detectó ninguna asociación entre el uso del condón femenino durante el último acto sexual y la presencia o ausencia de infección por VIH.

Conclusiones. Comparadas con las mujeres en riesgo de infección por VIH, las que tenían seropositividad a VIH en nuestro estudio mostraron mayores probabilidades de usar condones masculinos con su pareja, de acudir a sus consultas de seguimiento, y de someterse a un seguimiento más prolongado. Entre las mujeres con positividad a VIH que participaron en este estudio, el grado de aceptación del condón femenino, según indicaron en su primera consulta de seguimiento, se asemeja al de las mujeres brasileñas en general. 